Mgr Przemysław Terejko

UMCS Lublin

e-mail: przemekterejko@wp.pl

\title{
Changing Conventions of Computer-Mediated Communication
}

\section{Introduction}

In the article, our primary aim is to verify the expectation that the so-called netiquette, that is the conventions governing computer-mediated communication, has changed since its first formulation in the early $90 \mathrm{~s}$. What makes us ascribe this change is the advent of new modes of interaction that have become available for the internet users. In our research, therefore, we shall compare the conventions established for the early virtual communities with their modern versions formulated for a newly-emergent mode of interaction, namely social networking. Our other aim will be to investigate the course of the identified changes and explain their motivations, which, in turn, will allow us to draw some conclusions regarding the novel conventions regarding computer-mediated communication (CMC).

The present piece of research can be placed within the general framework of functional linguistics. There are at least two points of convergence between our research and functionally-oriented paradigms. Firstly, one of the major characteristics of functionalism is that it takes communication to be the basic function of language ${ }^{1}$. Accordingly, the subject of our study is communicative conventions which constitute "the central aspect of the communicative use of language" we do realize that linguistic functionalism may be given different names and, at times, one is unable to draw the line between functionalism and non-functionalism,

1 C.S. Butler, Functional Approaches to Language, [in:] The Dynamics of Language Use: Functional and Contrastive Perspectives, eds. C. Butler, M. Gómez-González, S. Doval Suárez, Amsterdam-Philadelphia: John Benjamins Publishing 2005, DOI: http://dx.doi.org/10.1075/ pbns.140.04but, pp. 3-19.

2 W. Croft, Explaining Language Change: an Evolutionary Perspective, Harlow: Pearson Education Limited 2000, p. 7. 
even in reference to what appears to be akin methodologies, such as cognitive and functional ones. As Przemysław Łozowski exemplifies the problem, "on the one hand, Langacker hopes for what he calls »a global synthesis « ${ }^{3}$ of cognitive and functional linguistics, yet, on the other hand, he does not see any immediate necessity of incorporating functional parameters into the description of grammar"4. To make it clear, the reading we give to functionalism is that of experience-based linguistic communication, or, as Łozowski puts it: „language is a derivative, not a determinant, of culture and cognition - it is not that language allows for our experience, but, rather, that our experience facilitates our language"s. In short, the kind of functional communication that we favour here amounts to verbalizing conceptualizations of our experience, netiquette included.

Secondly, functional theories emphasize the importance of both socio-cultural and psychological contexts of interaction ${ }^{6}$. In other words, functionalists believe that language is not an autonomous system independent of external factors, but it is influenced, or even predetermined, by them. In our research, we adopt the same line of argument by focusing on a very specific context of computer-mediated communication. Moreover, we mean to establish the ways in which the unique characteristics of such medium influence the communicative conventions followed by the internet users. Ultimately, the study can be classified as lying within the scope of Computer Mediated Discourse Analysis (CMDA) - the paradigm initiated by Susan Herring. The research can be specifically interpreted as investigating the transfer from static, single-authored web, referred to as $\mathrm{Web} 1.0$ to more dynamic, interactive websites focused on sharing user-generated content, collaboration and socialisation, which are covered by the term $\mathbf{W e b} \mathbf{2 . 0 ^ { 7 }}$.

As the reported piece of research relies heavily on the understanding of the concept of convention as well as its application to the communication in general and the computer-mediated variation of it in particular, the analytical part of the

3 R.W. Langacker, Concept, Image, and Symbol. The Cognitive Basis of Grammar, $2^{\text {nd }}$ ed., Berlin-New York: Mouton de Gruyter 2002, p. 344.

${ }^{4}$ P. Łozowski, Kognitywizm i funkcjonalizm: razem czy osobno?, [in:] Kognitywistyka: problemy i perspektywy, eds. H. Kardela, Z. Muszyński, M. Rajewski, Lublin 2005, p. 211. Translation ours.

5 Idem, Dialog doświadczenia z tradycją: postmodernizm na barykadach modernizmu, [in:] Dialog z tradycją: język - komunikacja - kultura, eds. R. Dźwigoł, I. Steczko, Vol. 3, Kraków 2015, pp. 50-51. Translation ours. For more details, see idem, Experience behind Language: Panchronic Motivation behind Polish Names of the Months, [in:] Sound, Structure and Sense. Studies in Memory of Edmund Gussmann, eds. E. Cyran, H. Kardela, B. Szymanek, Lublin 2012, pp. 407-420.

${ }^{6}$ C.S. Butler, op. cit., p. 4.

7 S. Herring, Discourse in Web 2.0. Familiar, Reconfigured, and Emergent, [in:] Discourse 2.0: Language and New Media, eds. D. Tannen, M. Tester, Washington, DC: Georgetown University Press 2013, pp. 1-25. 
paper is preceded by a theoretical introduction to the issues in question. Firstly, the notion of communicative convention will be introduced. Secondly, the discussion shall focus on the conventions of online interactions codified in netiquette. After those preliminary remarks, the actual study will be presented. The article closes with a set of conclusions that can be drawn from the reported piece of research.

\section{Communicative Conventions and their Application to CMC}

The Oxford English Dictionary defines convention as ,general agreement or consent, deliberate or implicit, as constituting the origin and foundation of any custom, institution, opinion etc., or as embodied in any accepted usage, standard of behaviour, method of artistic treatment, or the like" ${ }^{8}$. If we substitute the generalisations of this definition with the specific issue of communication, we obtain the definition of convention which is the subject of the present article. The communicative convention can be, therefore, defined as general agreement or consent, deliberate or implicit, as constituting the origin and foundation of communicative behaviour, or embodied in any accepted cases or standards of communication. We are aware, however, that communication is a vastly broad term, covering many types of linguistic and nonlinguistic intentional activity, taking place in numerous contexts and often via different media. Each context or medium may create own communicative conventions that take into consideration its unique features. Face-to-face communication, for example, is generally ruled by different conventions than letter-writing, which are, in turn, different to the ones governing telephone calls.

One of the first philosophical attempts at accounting for the notion of social convention, so also the one governing the communicative use of language, was made by David Lewis9. Among a number of features characteristic of convention, Lewis included the one assuming the existence of an alternative way of achieving the desired goal. In other words, it is common to achieve this goal in the conventional manner, but it can also be done differently. We believe that such condition makes it possible to account for the changes of convention under certain circumstances - a characteristic important for our further inquiries.

Bearing the two abovementioned features of communication (its context-dependence) and convention (its changeability) in mind, we decided to focus our study on a specific set of conventions characteristic to a relatively new communicative medium, namely the internet. We put forward a hypothesis that the conventions governing online interactions have changed since they were first formulated

8 The Oxford English Dictionary, eds. J.A.H. Murray [et al.], Vol. 3, Oxford: Oxford University Press 1989, p. 864.

9 See D.K. Lewis, Convention: A Philosophical Study, Cambridge, MA: Harvard University Press 1969. 
in the early years of the existence of the medium. We believe that the rapid increase of the number of the internet users, which has gone up from 14161570 in 1993 to 2925249355 in $2014^{10}$, combined with the unique features of this medium and the appearance of new modes of online interaction, such as social networking, support the validity of such research question.

The communicative conventions of computer-mediated communication are codified in netiquette. Linguistically, the term is a compound of two nouns, network and etiquette, and as such can be defined as a social code of behaviour applicable to network communication ${ }^{11}$. This "code of behavior" specifies what is appropriate on the internet, so it is also a set of ethical rules established in order to facilitate interactions over computer networks. According to Michał Pręgowski ${ }^{12}$, one of the key characteristics of netiquette is its heterogeneousness. There is no one, generally accepted document that could be called "the Netiquette". Instead, there are many versions differing in contents (different documents may focus on different aspects of online activity), accuracy (they may focus on them in greater or smaller detail), universality (they can be applied to the internet as a whole or to just one local community) and addressees (they can be aimed at the users of a specific mode or coming from one country).

David Chiles ${ }^{13}$ binds the beginnings of netiquette with the beginnings of the internet. He claims that the first instance of using a computer for communicative purposes marks the first practical application of netiquette as the users engaging in this first ever computer-mediated interaction had to follow some "cultural conventions" in order to make this act possible ${ }^{14}$.

Pręgowski ${ }^{15}$, on the other hand, traces back the origins of the term "netiquette" to 1992 and an internal document of American National Science Foundation. This document was preceded by A Primer on How to Work With the Usenet Community - an instruction written in the 80 s by Chuq von Rospach, who is considered to be the father of the term. It may seem surprising that formally written netiquettes appeared so late in the history of the internet, which dates back to the 1960s. Manuel

${ }^{10}$ Internet Live Stats. Internet Users, [online]. Available on the internet: www.internetlivestats.com/internet-users/\#trend [accessed: 25 March 2015].

11 D.P. Chiles, The Principles of Netiquette, Published by David Paul Chiles 2013, p. 7.

12 M.P. Pręgowski, Wzór osobowy internauty: czego oczekują od nas netykiety, „Studia Socjologiczne" 2009, No. 2 (193), pp. 109-130.

13 D.P. Chiles, op. cit., pp. 7-8.

14 This is an evidence of another feature of netiquette, namely the fact that it is based on some more general principle governing social life as whole. Chiles calls it the "Golden Rule" and formulates it in the form of a commandment "Treat others the way you want to be treated" (ibidem, p. 6). For Vincent's understanding of such principle, see the following part of the article.

15 M.P. Pręgowski, op. cit., pp. 2-3. 
Castells ${ }^{16}$ puts it down to the fact that the early communities of internet users were quite small, therefore able to self-regulate. Their members were characterised by the same, high technological competence and a common set of values, which were adopted by the people joining the communities. The situation changed in the $90 \mathrm{~s}$. The growing popularity and accessibility of the internet resulted in enormous numbers of new users who were not aware of the conventions present in the virtual world. The first netiquettes were formulated as universal, accessible and straightforward guidelines for such "newbies".

As the network kept evolving and providing the users with new possibilities and services, the early netiquettes served the purpose of being a template on which numerous reformulations and adaptations were shaped. The result is the heterogeneous set of rules, created and agreed on by the internet users for the internet users, specifying the accepted standards of computer-mediated communication.

\section{Material and Methods}

The study included seven netiquettes containing over three hundred rules ${ }^{17}$. The documents were selected according to the date of their publication. The first two were published in the $1990 \mathrm{~s}$, so they represent the conventions governing computer-mediated communication in the early years of its popularity. The other five netiquettes were published after the year $2008^{18}$. An additional criterion for their selection was the fact that they focus on a novel type of computer-mediated interaction, namely social networking. As a result, they should represent the modern conventions of computer-mediated communication. The comparison of the two groups will allow us to verify the initial hypothesis that the conventions governing online communication have changed with the advent of new modes of online interaction.

The analysis was carried out in two stages. As the basis for the first stage, we adopted Michel Marcoccia's categories of netiquette rules, as reported by Jocelyne Vincent ${ }^{19}$. The categories cover six areas in which problems in CMC may arise. As the original study was published in French and Vincent's account of it is too

\footnotetext{
16 M. Castells, Galaktyka Internetu, trans. T. Hornowski, Poznań 2003.

17 The list of all analysed documents can be found at the end of the article. The documents are henceforth referred to by the name of the author.

18 When collecting the data, we were mostly focused on the number of rules into each group, not the number of documents.

19 J. Vincent, Netiquette Rules, OK!... OK?: Speculating on Rhetorical Cleansing and English Linguistic and Cultural Imperialism through Email Netiquette Style Guides, [in:] Threads in the Complex Fabric of Language: Linguistic and Literary Studies in Honour of Lavina Merlini Barbaresi, eds. M. Bertuccelli Papi, A. Bertacca, S. Bruti, San Giuliano Terme 2008, pp. $425-427$.
} 
vague to be a firm basis for further research, we decided to introduce some specifications to Marcoccia's classification. The first category was meant to deal with the issues of politeness. In our study, we understand it in terms of face-management ${ }^{20}$, which is the original specification reported by Vincent, but also include all the rules dealing with imposing one's company upon other users, for instance by sending mass messages or invitations, and good manners. The second category was branded cooperation. We understand it in the strictly Gricean ${ }^{21}$ sense, so we include all the rules dealing with conversational maxims, especially the Maxim of Quantity (the rules specifying the length of contributions and quoting) and the Maxim of Relevance (the rules ordering the users to speak to the point, forbidding gratuitous replies and using the network in appropriate ways). The third category is focused upon the contents of messages. It includes all the rules forbidding flaming, commercial messages as well as the messages containing culture-specific information. The fourth category proposed by Marcoccia encompasses the rules dealing with the identification and anonymity of the users, that is ordering them, or occasionally allowing not to, provide their personal information. The fifth category is focused on real-life laws. Here, we include all the calls for obeying copyright as well as providing references for the posted material. The final category deals with the adaptation to the constraints of the medium. We decided to include under this heading all the rules specifying the typing conventions, such as using emoticons, upper case and acronyms, and solving the problems stemming from the unique characteristics of CMC.

Marcoccia's classification was created in 1998 and was based on the early and, in a sense, canonical formulations of netiquette. As such, it provides a good representation of the early communicative conventions present on the internet. In order to establish whether the conventions have changed over the years and with the advent of new modes of CMC, we added one more category to Marcoccia's original six, namely the category of "other". It would contain the rules that cannot be subsumed under any of the original headings. In the second stage or the research, we shall look more closely at those rules in an attempt to investigate the directions in which the communicative conventions of CMC have changed. We shall also draw some conclusions trying to explain the course of the identified changes.

20 See P. Brown, S.C. Levinson, Politeness: Some Universals in Language Usage, Cambridge: Cambridge University Press 1987.

21 See H.P. Grice, Studies in the Way of Words, Cambridge, MA: Harvard University Press 1989. 


\section{Results and analysis}

The results of the first stage of the study are presented in Table 1 .

Table 1. Old and new netiquettes in relation to Marcoccia's categories

\begin{tabular}{|c|c|c|c|c|c|c|c|}
\hline \multirow[b]{2}{*}{ Document } & \multicolumn{7}{|c|}{ Category } \\
\hline & Politeness & $\begin{array}{c}\text { Coopera- } \\
\text { tion }\end{array}$ & Contents & \begin{tabular}{|c|} 
Identifica- \\
tion/ano- \\
nymity
\end{tabular} & $\begin{array}{c}\text { Real-life } \\
\text { laws }\end{array}$ & \begin{tabular}{|c|} 
Adaptations \\
to the fea- \\
tures of the \\
medium
\end{tabular} & Other \\
\hline $\begin{array}{l}\text { Rinaldi (1996, } \\
58 \text { examples) }\end{array}$ & $24,1 \%$ & $15,5 \%$ & $13,8 \%$ & $5,2 \%$ & $5,2 \%$ & $29,3 \%$ & $6,9 \%$ \\
\hline $\begin{array}{l}\text { Hambridge }^{22} \\
(1995, \\
94 \text { examples) }\end{array}$ & $33 \%$ & $14,9 \%$ & $14,9 \%$ & $4,3 \%$ & $4,3 \%$ & $22,3 \%$ & $6,4 \%$ \\
\hline $\begin{array}{l}\text { Summary } \\
\text { (152 examples) }\end{array}$ & $\begin{array}{c}45 \\
(29,6 \%) \\
\end{array}$ & $\begin{array}{c}23 \\
(15,1 \%) \\
\end{array}$ & $\begin{array}{c}22 \\
(14,5 \%) \\
\end{array}$ & $\begin{array}{c}7 \\
(4,6 \%) \\
\end{array}$ & $\begin{array}{c}7 \\
(4,6 \%) \\
\end{array}$ & $\begin{array}{c}38 \\
(25 \%) \\
\end{array}$ & $\begin{array}{c}10 \\
(6,6 \%) \\
\end{array}$ \\
\hline $\begin{array}{l}\text { Samuel (2011, } \\
25 \text { examples) }\end{array}$ & $20 \%$ & $24 \%$ & $8 \%$ & $4 \%$ & $8 \%$ & $0 \%$ & $36 \%$ \\
\hline $\begin{array}{l}\text { Balinas } 2014, \\
(25 \text { examples) }\end{array}$ & $16 \%$ & $12 \%$ & $12 \%$ & $0 \%$ & $4 \%$ & $12 \%$ & $44 \%$ \\
\hline $\begin{array}{l}\text { Weinberg } 2008 \\
\text { (39 examples) }\end{array}$ & $35,9 \%$ & $7,7 \%$ & $10,3 \%$ & $5,1 \%$ & $5,1 \%$ & $2,6 \%$ & $33,3 \%$ \\
\hline $\begin{array}{l}\text { Moltz (2011, } \\
20 \text { examples) }\end{array}$ & $15 \%$ & $15 \%$ & $5 \%$ & $0 \%$ & $0 \%$ & $10 \%$ & $55 \%$ \\
\hline $\begin{array}{l}\text { Online Degree } \\
\text { Programs } \\
(2010, \\
50 \text { examples })\end{array}$ & $26 \%$ & $6 \%$ & $12 \%$ & $6 \%$ & $0 \%$ & $16 \%$ & $34 \%$ \\
\hline $\begin{array}{l}\text { Summary } \\
\text { (159 examples) }\end{array}$ & \begin{tabular}{|c|}
39 \\
$(24,5 \%)$ \\
\end{tabular} & $\begin{array}{c}18 \\
(11,3 \%)\end{array}$ & $\begin{array}{c}16 \\
(10,1 \%) \\
\end{array}$ & $\begin{array}{c}6 \\
(3,8 \%) \\
\end{array}$ & \begin{tabular}{|c|}
5 \\
$(3,1 \%)$ \\
\end{tabular} & $\begin{array}{c}14 \\
(8,8 \%) \\
\end{array}$ & \begin{tabular}{|c|}
61 \\
$(38,4 \%)$ \\
\end{tabular} \\
\hline
\end{tabular}

The top part of the table presents the results of the analysis of the two early formulations of netiquette. The bottom part, in turn, presents the outcomes of the analysis for the new documents formulated with social networking in mind. The first observation that can be made at this point is the sizeable amount of overlap between the two groups. Both of them contain comparable proportions of rules dealing with five original categories proposed by Marcoccia. It stems from the fact that his analysis, as well as the first section of the present study, took into consideration the most canonical formulations of the code of online conduct. The netiquettes by Sally Hambridge and Arlene Rinaldi are considered to be classics

${ }^{22}$ As the rules for administrators included into this document are not concerned with communication between the users, they were not taken into account in the study. 
in the field, as a result they have become a template on which other formulations have been moulded. Moreover, all netiquettes are based upon the frame of universal and general rules applicable to all kinds of communicative behaviour. Vincent derives such "golden rule" from Kant's categorial imperative saying "act only in accordance with that maxim through which you can at the same time will that it become a universal law" ${ }^{\prime 23}$. In other words, the internet users should treat other participants in the same way as they would like to be treated. Examples supporting this general claim can be found in all the analysed documents and are formulated in various ways. Barry Moltz, for example, advises the users to "be respectful of everyone's blog. It's like their house. Would you want someone coming into your house stomping and telling you how ugly it looks?".

The sixth category of Marcoccia's classification, however, shows a great disproportion, with the quarter of rules from the old netiquettes and just $8,8 \%$ from the more recent ones dealing with it. This category deals with the adaptations to the features of the medium, in other words, the fact that the interactions take place in the unique environment which imposes certain types of behaviour. The detailed analysis of the rules from the first two documents shows that the majority of them $(55,3 \%)$ deal with the fact that the interactions take place via electronic devices. As a result, the users are warned, for example, that "the cost of delivering an e-mail message is, on the average, paid about equally by the sender and the recepient [...]. Sending someone mail may also cost them in other specific ways like network bandwidth, disk space or CPU usage." (Hambridge) or are told to "delete unwanted messages immediately since they take up disk storage" (Rinaldi). Apart from dealing with technological constraints, the users are also advised how to cope with other medium-specific problems, such as the lack of contextual clues. As a result, they are guided, for instance, in the use of emoticons, abbreviations and other symbols that have become online communicative conventions. Hambridge, for instance, advices the users to "use smileys to indicate tone of voice, but use them sparingly. :-) is an example of a smiley (look sideways). Don't assume that the inclusion of a smiley will make the recipient happy with what you say or wipe out an otherwise insulting comment".

The second group of documents also deals with the medium-specific issues, but places much smaller emphasis on them. What is more, of fourteen rules in this category, none is focused on hardware or software restrictions. Instead, they regulate the typing conventions and the use of symbols such as "\#”24 and “@”"25.

23 J. Vincent, op. cit., p. 421.

24 “\#Don't \#Abuse \#Hashtags. Hashtags are a good way to help get your tweets and Facebook posts categorized with similar content so when someone searches for that keyword, they find you. This does not mean that you turn every word into a post a hashtag" (Balinas).

25 “Know what@means: @ is a sign that means you're responding to or directly addressing a particular user or message. On some sites, it even tags that person" (Online Degree Programs). 
The reason for such neglect of the questions of technological limitations and costs can be that such issues are no longer relevant for an average internet user due to the technological progress that has taken place. The internet services have become so cheap, and hardware possibilities so huge, that the costs and limitations are no longer a reason for concern.

However, the most important category from the point of view of the present study is the last one, not included in Marcoccia's classification. It contains the rules that cannot be unambiguously placed in any other category. While the low value for the early netiquettes can be explained by the fact that Marcoccia's study was to a large extent based on them, the fact that the more recent formulations differ from the original so much seems to corroborate our initial hypothesis. In the second part of the analysis, we focused only on these differences in an attempt to supplement Marcoccia's classification with the categories applicable for social networking. The results of this part of the study are presented in Table 2.

Table 2. The rules of social networking - new categories

\begin{tabular}{|c|c|c|c|c|c|c|}
\hline \multirow[b]{2}{*}{ Document } & \multicolumn{6}{|c|}{ Category } \\
\hline & $\begin{array}{c}\text { Limited } \\
\text { trust }\end{array}$ & Tolerance & $\begin{array}{l}\text { Virtual } \\
\text { identity }\end{array}$ & Discretion & $\begin{array}{l}\text { Activeness/ } \\
\text { helpfulness }\end{array}$ & $\begin{array}{c}\text { Real-life } \\
\text { context }\end{array}$ \\
\hline $\begin{array}{l}\text { Samuel } 2011 \\
\text { (9 examples) }\end{array}$ & $0 \%$ & $11,1 \%$ & $44,4 \%$ & $11,1 \%$ & $33,3 \%$ & $0 \%$ \\
\hline $\begin{array}{l}\text { Balinas } 2014 \\
\text { (11 examples) }\end{array}$ & $0 \%$ & $0 \%$ & $36,4 \%$ & $9,1 \%$ & $54,5 \%$ & $0 \%$ \\
\hline $\begin{array}{l}\text { Weinberg } 2008 \\
\text { (13 examples) }\end{array}$ & $0 \%$ & $7,7 \%$ & $69,2 \%$ & $7,7 \%$ & $15,4 \%$ & $0 \%$ \\
\hline $\begin{array}{l}\text { Moltz } 2011 \\
\text { (11 examples) }\end{array}$ & $0 \%$ & $9,1 \%$ & $9,1 \%$ & $18,2 \%$ & $9,1 \%$ & $54,5 \%$ \\
\hline $\begin{array}{l}\text { Online Degree } \\
\text { Programs } 2010 \\
\text { (17 examples) }\end{array}$ & $5,9 \%$ & $0 \%$ & $35,3 \%$ & $5,9 \%$ & $29,4 \%$ & $23,5 \%$ \\
\hline $\begin{array}{l}\text { Summary } \\
\text { (61 examples) }\end{array}$ & $1(1,6 \%)$ & $3(4,9 \%)$ & $24(39,3 \%)$ & $6(9,8 \%)$ & $17(27,9 \%)$ & $10(16,4 \%)$ \\
\hline
\end{tabular}

The biggest number of rules dealt with the issue of, what we called, virtual identity. This category contained the rules specifying the image of oneself that is created by each user of a social networking service. It needs to be stressed at this point that this image consists of much more than just the identifying pieces of information. That is why the rules that fell into this category did not fit into Maroccia's original "Identification/anonymity" group. Virtual identity is about the way a person is perceived online. Most commonly, the rules order the users to "humanise" their profiles, that is to "add at least an avatar and a bio. Let people know who you are" (Weinberg). Another crucial aspect is ensuring that the im- 
age is true by, for instance, providing real and non-edited photos (Online Degree Programs) or avoiding following people just to "inflate your numbers" (Weinberg). Another aspect of virtual identity that is scolded by the netiquettes is egocentrism. Three of the analysed documents incorporated the rules encouraging the users to "promote OTHERS more than you promote yourself. The rule of thumb is 10:1. For every one thing you say to promote yourself you should say 10 things NOT about yourself" (Samuel). The netiquettes also promote consistency in creating the virtual image. Some of the rules advise the users to "use the same photo on all social media sites for professionalism and continuity of your brand" (Moltz) while others even forbid having multiple profiles because it is "just as hard as it is to try and live two separate lives" (Balinas).

The second most prominent category is connected to activeness/helpfulness when using social media. It contains the rules promoting (or occasionally limiting) creating links between users and encouraging them to share their knowledge and skills with others. A typical example of such rules say that "you can earn respect on social media sites by offering high quality, accessible information in a friendly way. Share relevant links, commentary and helpful advice" (Online Degree Programs). We believe that the prominence given to such rules stems from what Alfred Weaver and Benjamin Morrison call "bottom-up creation of information and interaction" ${ }^{26}$. The internet is no longer a place where large organizations are the sole, authoritarian source of knowledge. Instead, it has become a breeding ground for cooperation, creating and sharing content by everyone willing to do $\mathrm{so}^{27}$. Active participation in this process has become a vital part of social media etiquette.

The next, significant category deals with what we call "the real-life context". The rules in this category, even though quite numerous, appear only in two of the analysed documents so it seems reasonable to assume that they have not become fully universal yet. The real-life context includes such aspects of online interaction as "tweeting under the table in meetings" (Moltz) or "sending drunk Facebook messages or making drunk wall posts" (Online Degree Programs).

The category of discretion, even though less numerous, seems to be more universal because at least one example of it can be found in every document. Discretion most commonly refers to "tagging individuals in unflattering pictures" (Weinberg) or posting embarrassing videos (Moltz).

The last two categories that are minutely represented in the study focus on tolerance, that is not getting angry at the lack of other users' knowledge, and what

26 A. Weaver, B. Morrison, Social Networking, "Computer" 2008, No. 41, p. 97.

27 Features such as "participatory information sharing, user-generated content [and] an ethic of collaboration" became the basis for drawing the distinction between Web 1.0 and Web 2.0. S. Herring, op. cit., p. 2. 
we call "limited trust", that is not believing in everything that can be found on the internet. Even though marginally represented in social media netiquettes, these categories are present in the documents from the 90s (five rules from the category of "other"). This can be seen as another argument supporting the initial hypothesis that the conventions of $\mathrm{CMC}$ have undergone some changes. One of them is the fact that in the early days the users had to be reminded that the content encountered on the internet can be "subject to forgery and spoofing" and that they should "apply common sense reality checks before assuming a message is valid" (Hambridge). Nowadays, however, such reminders seem irrelevant as the users have grown accustomed to the medium and its characteristics.

\section{Conclusions}

The presented study corroborated the initial hypothesis that the conventions governing computer-mediated communication have changed with the advent of the new mode of interaction. Even though the two analysed groups of netiquettes showed a great deal of overlap with regard to the universal rules governing all kinds of social interaction, their treatment of the medium-specific aspects was substantially different. We established that modern etiquettes do not place such great emphasis on the technical issues connected with computer-mediated communication as the old ones. Instead, they prefer to guide the users in the aspects characteristic of the new mode of interaction, such as creating and managing their virtual identity or being active and helpful towards others.

\section{Netiquettes used in the study}

Balinas T., Social Media Etiquette for Business: 25 Do's \& Don'ts, [online] 30 July 2014. Available on the internet: www.business2community.com/social-media/social-media-etiquette-business-25-dos-donts-0960691 [accessed: 1 April 2015].

Hambridge S., Netiquette Guidelines, [online] October 1995. Available on the internet: www.ietf.org/rfc/rfc1855.txt [accessed: 1 April 2015].

Moltz B., 20 New Keys To Social Media Etiquette, [online] 15 September 2011. Available on the internet: www.americanexpress.com/us/small-business/openforum/articles/20-new-keys-to-social-media-etiquette [accessed: 1 April 2015].

Online Degree Programs, Social Media Etiquette for Students: 50 Crucial Rules, [online] 29 March 2010. Available on the internet: www.onlinedegreeprograms.com/blog/2010/ social-media-etiquette-for-students-50-crucial-rules [accessed: 1 April 2015].

Rinaldi A., The Net: User Guidelines and Netiquette - Index, [online] 1 May 1996. Available on the internet: http://courses.cs.vt.edu/ cs3604/lib/Netiquette/Rinaldi [accessed: 1 April 2015]. 
Samuel A., 25 rules of social media netiquette, [online] 7 April 2011. Available on the internet: www.alexandrasamuel.com/world/25-rules-of-social-media-netiquette [accessed: 1 April 2015].

Weinberg T., The Ultimate Social Media Etiquette Handbook: Appendix A - The New Community Rules, [online] December 2008. Available on the internet: http://archive. oreilly.com/pub/a/digital-culture/excerpts/new-community-rules/ultimate-social-media-handbook.html [accessed: 1 April 2015].

\section{Streszczenie}

\section{Zmieniające się konwencje komunikacji internetowej}

W artykule autor przedstawia wyniki swojego badania, którego przedmiotem była netykieta, czyli niejednorodny zbiór zasad i konwencji przeznaczonych dla osób komunikujących się przez internet. Celem analizy było ustalenie, czy konwencje rządzące komunikacją internetową zmieniły się wraz z rozpowszechnieniem nowych form interakcji za pośrednictwem komputera. Opierając się na kategoriach zaproponowanych przez Michela Marcoccię (1998), autor porównuje zasady netykiety z lat dziewięćdziesiątych z ich współczesnymi odpowiednikami, identyfikując w ten sposób nowe konwencje rządzące światem wirtualnym.

Słowa kluczowe: netykieta; konwencja; komunikacja internetowa; językoznawstwo funkcjonalne

\section{Summary}

In the article, the author presents the results of the study of netiquette, that is, a multi-faceted collection of rules and conventions governing computer-mediated communication. The aim of the study was to establish whether these conventions have changed with the advent of new modes of online interaction. The research was based on the categories proposed by Michel Marcoccia (1998), against which some of the early formulations of netiquette and their modern versions were compared. Such comparison allowed the author to identify the areas of change as well as draw some conclusions regarding their origins and directions.

Keywords: convention; netiquette; computer-mediated communication; functionalism 


\section{Bibliography}

Brown P., Levinson S.C., Politeness: Some Universals in Language Usage, Cambridge: Cambridge University Press 1987.

Butler C.S., Functional Approaches to Language, [in:] The Dynamics of Language Use: Functional and Contrastive Perspectives, eds. C. Butler, M. Gómez-González, S. Doval Suárez, Amsterdam-Philadelphia: John Benjamins Publishing 2005, DOI: http://dx.doi.org/10.1075/pbns.140.04but, pp. 3-19.

Castells M., Galaktyka Internetu, trans. T. Hornowski, Poznań 2003.

Chiles D.P., The Principles of Netiquette, Published by David Paul Chiles 2013.

Croft W., Explaining Language Change: an Evolutionary Perspective, Harlow: Pearson Education Limited 2000.

Grice H.P., Studies in the Way of Words, Cambridge, MA: Harvard University Press 1989. Herring S., Discourse in Web 2.0. Familiar, Reconfigured, and Emergent, [in:] Discourse 2.0: Language and New Media, eds. D. Tannen, M. Tester, Washington, DC: Georgetown University Press 2013, pp. 1-25.

Internet Live Stats. Internet Users, [online]. Available on the internet: www.internetlivestats.com/internet-users/\#trend [accessed: 25 March 2015].

Langacker R.W., Concept, Image, and Symbol. The Cognitive Basis of Grammar, $2^{\text {nd }}$ ed., Berlin-New York: Mouton de Gruyter 2002.

Lewis D.K., Convention: A Philosophical Study, Cambridge, MA: Harvard University Press 1969.

Łozowski P., Dialog doświadczenia z tradycją: postmodernizm na barykadach modernizmu, [in:] Dialog z tradycją: język-komunikacja - kultura, eds. R. Dźwigoł, I. Steczko, Vol. 3, Kraków 2015, pp. 47-55.

Łozowski P., Experience behind Language: Panchronic Motivation behind Polish Names of the Months, [in:] Sound, Structure and Sense. Studies in Memory of Edmund Gussmann, eds. E. Cyran, H. Kardela, B. Szymanek, Lublin 2012, pp. 407-420.

Łozowski P., Kognitywizm i funkcjonalizm: razem czy osobno?, [in:] Kognitywistyka: problemy i perspektywy, eds. H. Kardela, Z. Muszyński, M. Rajewski, Lublin 2005, pp. 209-218.

Pręgowski M.P., Wzór osobowy internauty: czego oczekują od nas netykiety, „Studia Socjologiczne" 2009, No. 2 (193), pp. 109-130.

The Oxford English Dictionary, eds. J.A.H. Murray [et al.], Vol. 3, Oxford: Oxford University Press 1989.

Vincent J., Netiquette Rules, OK!... OK?: Speculating on Rhetorical Cleansing and English Linguistic and Cultural Imperialism through Email Netiquette Style Guides, [in:] Threads in the Complex Fabric of Language: Linguistic and Literary Studies in Honour of Lavina Merlini Barbaresi, eds. M. Bertuccelli Papi, A. Bertacca, S. Bruti, San Giuliano Terme 2008, pp. 409-443.

Weaver A., Morrison B., Social Networking, “Computer” 2008, No. 41, pp. 97-100. 